\title{
Alleviating arsenic toxicity to plants in a simulated cover system with phosphate placement in topsoil and subsoil
}

\author{
HM Anawar The University of Western Australia, Australia \\ P Damon The University of Western Australia, Australia \\ Z Rengel The University of Western Australia, Australia \\ DA Jasper MWH Australia Pty Ltd, Australia \\ M Tibbett University of Reading, UK
}

\begin{abstract}
Revegetation of arsenic-enriched mining wastes is challenging due to arsenic (As) toxicity to plants. Inorganic As is easily taken up by the cells of plant roots where it can disrupt plant metabolism partly due to its similarity to phosphate ions. Arsenic toxicity may be alleviated by phosphorus $(P)$ fertilisation partly due to the analogous chemical characteristics of phosphate and arsenate ions, although this effect may vary in different plant taxa.
\end{abstract}

Many mining cover systems employ a single layer, or multilayers, of soil or soil-like material directly over potential toxic waste material. We simulated this basic design in a glasshouse study by growing plants in a layered system (notionally topsoil and subsoil) where we tested how As and P interacted by assessing the effects of $P$ fertilisation (in topsoil and subsoil) on alleviating toxicity of As placed in subsoil only (to mimic a cover system).

Two contrasting plant species were used: a ryegrass (Lolium multiflorum) and an Acacia species grown in the mining area (Acacia ancistrocarpa). The growth of both plant species decreased in line with increased As concentrations in subsoil irrespective of high or low $P$ treatments to either topsoil or subsoil. Overall we found that $P$ application in topsoil (with As in the subsoil) was more effective than subsoil $P$ application for sustaining improved growth of plants by alleviating As toxicity.

\section{$1 \quad$ Introduction}

Arsenic (As) is one of the most potentially toxic elements for humans, animals and plants, classified by the U.S. Environmental Protection Agency as a group ' $A$ ' human carcinogen (Southworth 1995), ranked as the 20th most abundant element on the Earth and occurs in various redox-sensitive chemical forms (Datta \& Sarkar 2004). Mining, smelting and coal combustion have contributed the elevated levels of As to the environment for centuries (Adriano 1986; Marin et al. 1992).

Arsenic and inorganic phosphorus $(\mathrm{Pi})$ show chemical similarity due to their corresponding periodicity and comparable atomic radii (Manning \& Goldberg 1996). Arsenic interferes with $P$ uptake, an essential macronutrient for plant growth (Westheimer 1987). Interactions and competition of orthophosphate $(P(V))$ and arsenate $(\operatorname{As}(\mathrm{V}))$ at the surfaces of roots and soil particles play a key role for As and $\mathrm{P}$ transport across root plasma membrane (Quaghebeur \& Rengel 2004). Due to smaller size and higher charge of phosphate anions than $\mathrm{As}(\mathrm{V})$, Pi binds more strongly to soil surfaces than $\mathrm{As}(\mathrm{V})$ (Lambkin \& Alloway 2003), thereby facilitating the desorption of As into soil solution, and its subsequent uptake by plants (Smith et al. 2002; Fayiga \& Ma 2006). However, Pi can be also desorbed to soil solution at high As:Pi ratios due to the mass action effect of high As concentrations (Woolson et al. 1973; Roy et al. 1986). In contrast, application of $P$ fertiliser has been reported to decrease the availability of As in soils (Hanada et al. 1975) and hydroponics 
(Meharg \& MacNair 1992; Quaghebeur \& Rengel 2003; Shaibur et al. 2013), and increase uptake in plants, enhancing plant P status and biomass (Lei et al. 2012).

Given the innate toxicity of As to plants, the rehabilitation of As-rich mine wastes with native plant species in cover systems may be a challenge (Smith et al. 2010). There is little known of the potential efficacy of Pi fertilisation as a tool for alleviating As toxicity and while promoting plant growth in rehabilitated cover systems. In such systems it is typically difficult to recruit often slow growing native plant species on poor quality substrates. Furthermore, research to-date has focused on the interactions between As and Pi located together in soil, whereas in a cover system amended with $\mathrm{Pi}$, there will typically be a physical separation of the Pi applied to topsoil and As encapsulated in the subsoil.

Where arsenic may be present in the protected subsoil layers of cover systems, the plants grown on topsoil horizons can usually exploit all layers of the cover system through explorative root growth (Gwenzi et 2011; Spain \& Tibbett 2011; Spain et al. 2015; Taylor et al. 2003), and will ultimately encounter the As leading to possible toxicity. Using an experimental simulated cover system, we hypothesised that under elevated As concentration in subsoil, Pi fertilisation in topsoil will be more effective in alleviating As toxicity than where $P$ fertiliser is placed with As in the subsoil. This was achieved by growing a woody shrub (Acacia) and a common grass (ryegrass) on soils with various concentrations of $A$ s in subsoil and $P$ in either subsoil or topsoil. Plant uptake and toxicity symptoms and the influence of $\mathrm{P}$ placement in subsoil and topsoil were subsequently assessed in this system.

\section{$2 \quad$ Materials and methods}

\subsection{Experimental plan and soil materials}

Experimental materials were collected from the Telfer Newcrest gold mining site in Western Australia. Substrates included: Telfer sandy topsoil overlying Telfer crushed siltstone (outer siltstone member) and washed river sand. Plant species selected were a native shrub, local to the Telfer mine site, Acacia ancistrocarpa and a commonly used ryegrass Lolium multiflorum. The ryegrass is frequently used for phytostabilisation of metal-contaminated mining waste and slope stabilisation in mine site rehabilitation, and offers advantages of excellent establishment and quick growth (Alvarenga et al. 2008, 2009; Karami et al. 2011).

\subsection{Construction of layered cover system}

The PVC columns were lined with a plastic bag and the different soil substrates were layered simulating a miniaturised cover system as might be found in a store and release cover. The standardised layered columns were used ( $5 \mathrm{~cm}$ Telfer sandy topsoil overlying $5 \mathrm{~cm}$ Telfer crushed siltstone (outer siltstone member, OSM) and $10 \mathrm{~cm}$ washed river sand as subsoil). The OSM material had the following properties: $\mathrm{pH}$ (material:water 1:2) 6.4, EC (material:water 1:2) $0.9 \mathrm{dS} / \mathrm{m}$, total As (aqua regia) $12 \mathrm{mg} / \mathrm{kg}, \mathrm{CaCl}_{2}$-extractable As $0.032 \mathrm{mg} / \mathrm{kg}$, EDTA-extractable As $0.22 \mathrm{mg} / \mathrm{kg}$, total $\mathrm{Cu}$ (aqua regia) $42 \mathrm{mg} / \mathrm{kg}, \mathrm{CaCl}_{2}$-extractable Cu below detection limit, and EDTA-extractable Cu $5.8 \mathrm{mg} / \mathrm{kg}$. A capillary break (a 3-cm-thick layer of $2 \mathrm{~mm}$ diameter coarse plastic beads between the OSM and the subsoil layer) was included in all treatments to prevent capillary rise of water and ions from the subsoil to the upper layers. In treatment 1 , phosphorus was applied to topsoil and arsenic to subsoil, while in treatment 2 , both arsenic and phosphorus were added to subsoil (Figure 1).

\subsection{Design of As/P treatments}

Arsenic and $\mathrm{P}$ were applied at rates predicted to cause no medium or high toxicity to plants. In the As-P experiments, three As concentrations $(0,10$ or $64 \mathrm{mg} / \mathrm{kg}$ ) were applied in a factorial combination with two $P$ concentrations (10 or $100 \mathrm{mg} / \mathrm{kg}$ ), with P being applied either to subsoil (together with As) or topsoil (with As applied to subsoil to simulate a mining cover system). A complete basal nutrient blend (except $\mathrm{P}$ ) was applied to individual soil layers to encourage vigorous plant growth and minimise physiological interactions 
between the ion toxicity treatments and other nutrient deficiency in the plants. The selection of treatments was based on the preliminary experiments. Arsenic was applied as $\mathrm{Na}_{2} \mathrm{HAsO}_{4}$.
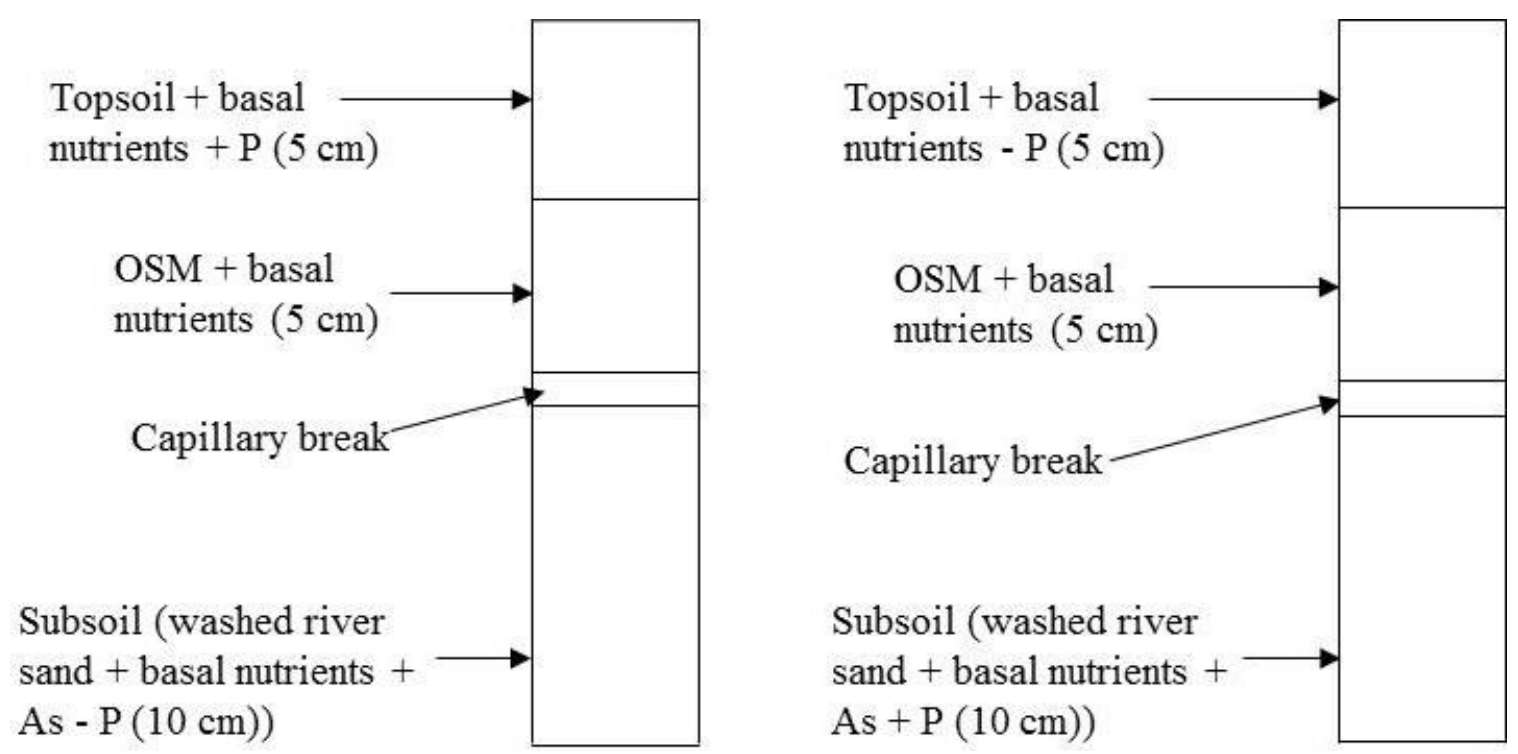

Figure 1 Construction of experimental three-layered soil system with varied treatments of arsenic and phosphorus shown in topsoil and subsoil layers. A mid-point capillary break and universal supplement of basal nutrient is shown

\subsection{Plant growth and harvesting}

Six Acacia or 20 ryegrass plants were grown per pot. Columns were placed in an evaporatively-cooled glasshouse at The University of Western Australia, Perth where temperature was maintained near $30^{\circ} \mathrm{C}$ and arranged in a completely randomised design. Topsoil was watered daily during seedling emergence to encourage the vigorous and uniform establishment of plants. Thereafter, the entire soil profile was brought to field capacity on a weekly basis by watering with de-ionised water to a pre-determined weight. The growth duration in different experiments was 72 days for Acacia and 42 days for ryegrass.

Plant growth was visually assessed and scored throughout the experiment to monitor the development of responses to the toxic ion treatments. The shoots were cut from the lower stem at the cotyledon node (for Acacia) or $0.5 \mathrm{~cm}$ above the soil surface (ryegrass), washed in $5 \mathrm{~mL} / \mathrm{L}$ acetic acid solution followed by three rinses in de-ionised water, dried at $65^{\circ} \mathrm{C}$ for 48 hours, weighed and analysed. Soil was removed from pots and cut at the boundary of each soil horizon. A small soil sample was collected from each soil horizon before soil was washed from roots under running water. Lower part of shoot (ryegrass) or hypocotyl (Acacia) was separated from the roots, dried and weighed. Shoot biomass was reported as the sum of upper part and lower part of shoot for ryegrass, and stem for Acacia weight. Elemental content of shoots was reported as the factor of upper shoot weight and the elemental concentration of upper shoots. The shoot material was digested in nitric/perchloric acid and analysed for toxic ions, nutrients and other elements by Inductively Coupled Plasma - Optical Emission Spectroscopy (ICP-OES) (Perkin-Elmer Optima 7300DV, Connecticut, USA).

\subsection{Statistical analysis}

All treatments were replicated three times. The statistical significance of the treatment effects was assessed using Genstat 14 statistical software. Herein, wherever the word 'significant' is used with respect to treatment effects or differences between means, the difference was statistically significant at the $95 \%$ confidence level. 


\section{$3 \quad$ Results}

\subsection{Treatment effects on ryegrass growth and As uptake}

Phosphate treatments at low and high rates (10 and $100 \mathrm{mg} / \mathrm{kg}$ ), to either topsoil or subsoil, partially alleviated the toxic effects of high As concentrations on shoot weight (Figure 2). For the subsoil P placement (together with As), the interaction between As and $\mathrm{P}$ concentrations was significant for ryegrass shoot growth, however, it was not significant at topsoil P application (Figure 2). The P placed in topsoil at the high rate decreased As uptake by shoot compared to subsoil application due to larger plant growth and presumably a dilution effect.
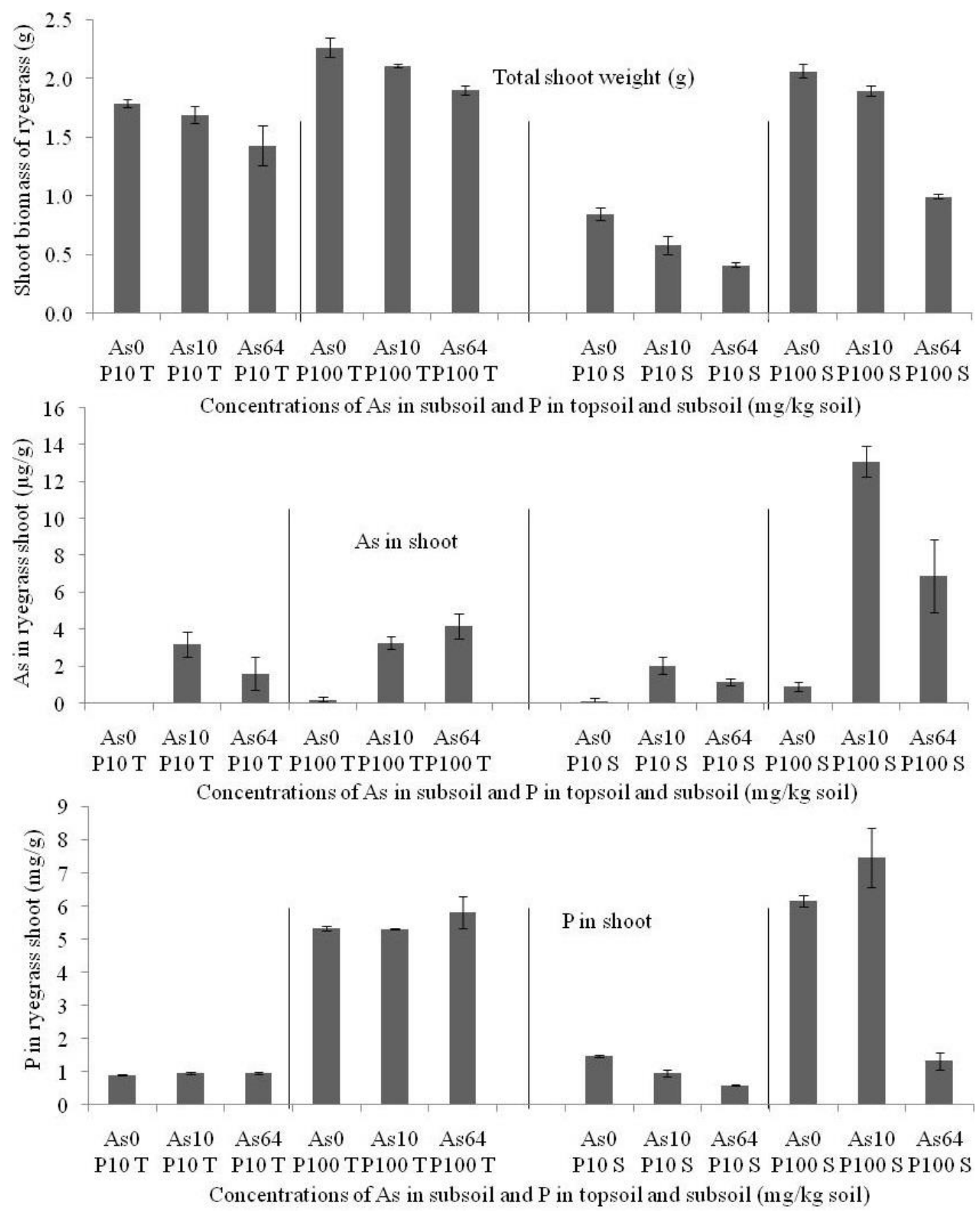

Figure 2 Mean dry shoot weight $(\mathrm{g} \pm \mathrm{SE}, \mathrm{n}=3$ ) of ryegrass plants grown in different $A$ s and $\mathrm{P}$ treatments (As in subsoil and $\mathrm{P}$ in either topsoil or subsoil) and As and $\mathrm{P}$ accumulation by ryegrass shoots 
Overall, the topsoil, OSM and subsoil root biomass at high $\mathrm{P}$ treatment were higher than that at low $\mathrm{P}$ treatment (Figures 3, 4 and 5). It was higher at topsoil $P$ treatment than subsoil $P$ treatment (Figures 3, 4 and 5). The topsoil and OSM root biomass of ryegrass at topsoil $P$ treatment at both low and high rates was higher than that at subsoil $P$ treatment (Figures 3 and 4). The subsoil root biomass at both topsoil and subsoil $P$ treatments at both rates, except subsoil low rate, were almost similar (Figure 5). At both topsoil and subsoil $P$ treatments (both low and high rates), the As concentrations in topsoil, OSM and subsoil root increased with the increase in As concentrations in treatments (Figures 3, 4 and 5). Similar to the root biomass, the $P$ concentrations in topsoil and OSM root at topsoil $P$ treatment at both low and high rates were higher than that at subsoil $P$ treatment.
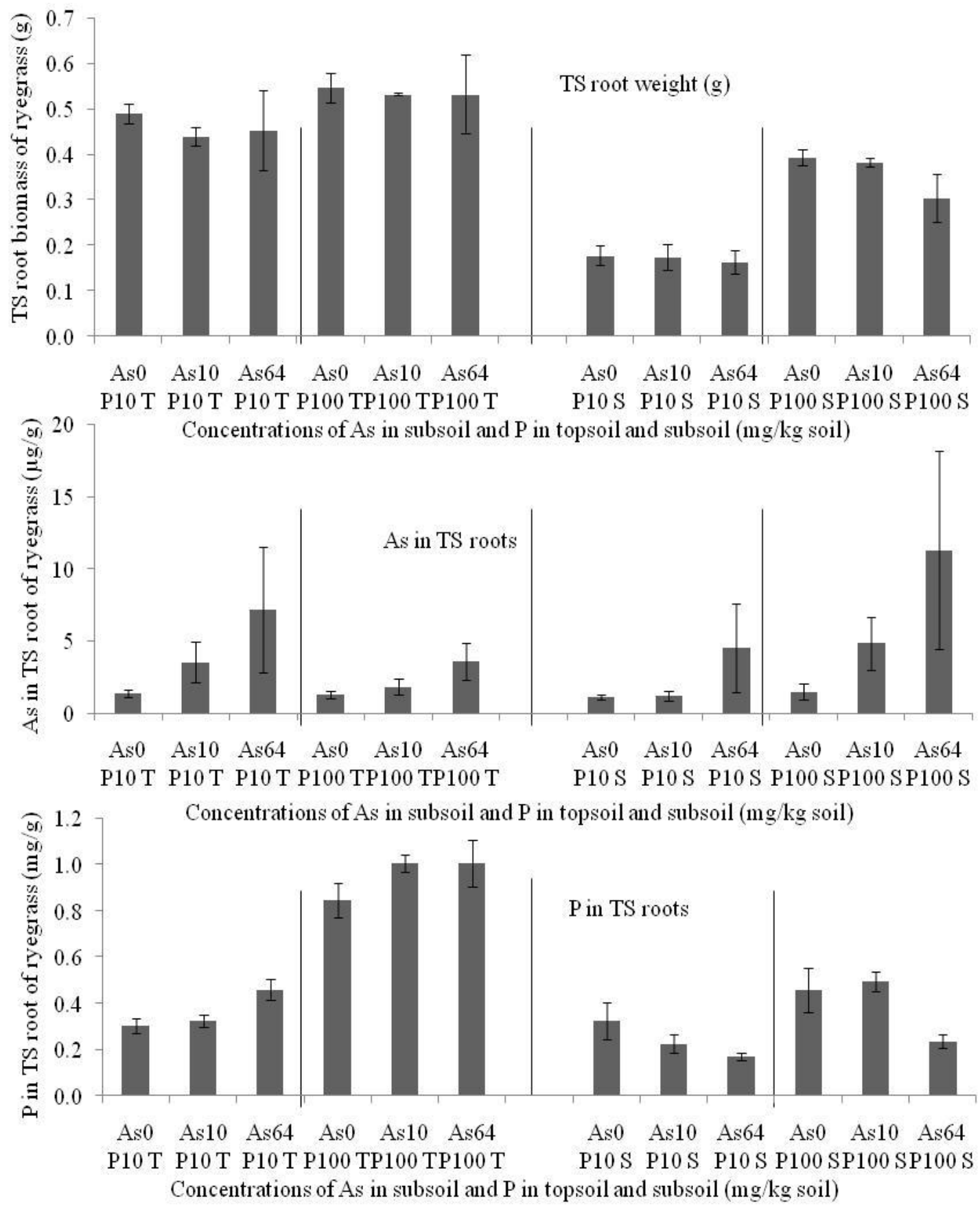

Figure 3 Mean dry topsoil (TS) root weight $(g \pm S E n=3$ ) of ryegrass plants grown in different $A s$ and $P$ treatments (As in subsoil and $\mathrm{P}$ in either topsoil or subsoil), and As and $\mathrm{P}$ accumulation by ryegrass topsoil roots 

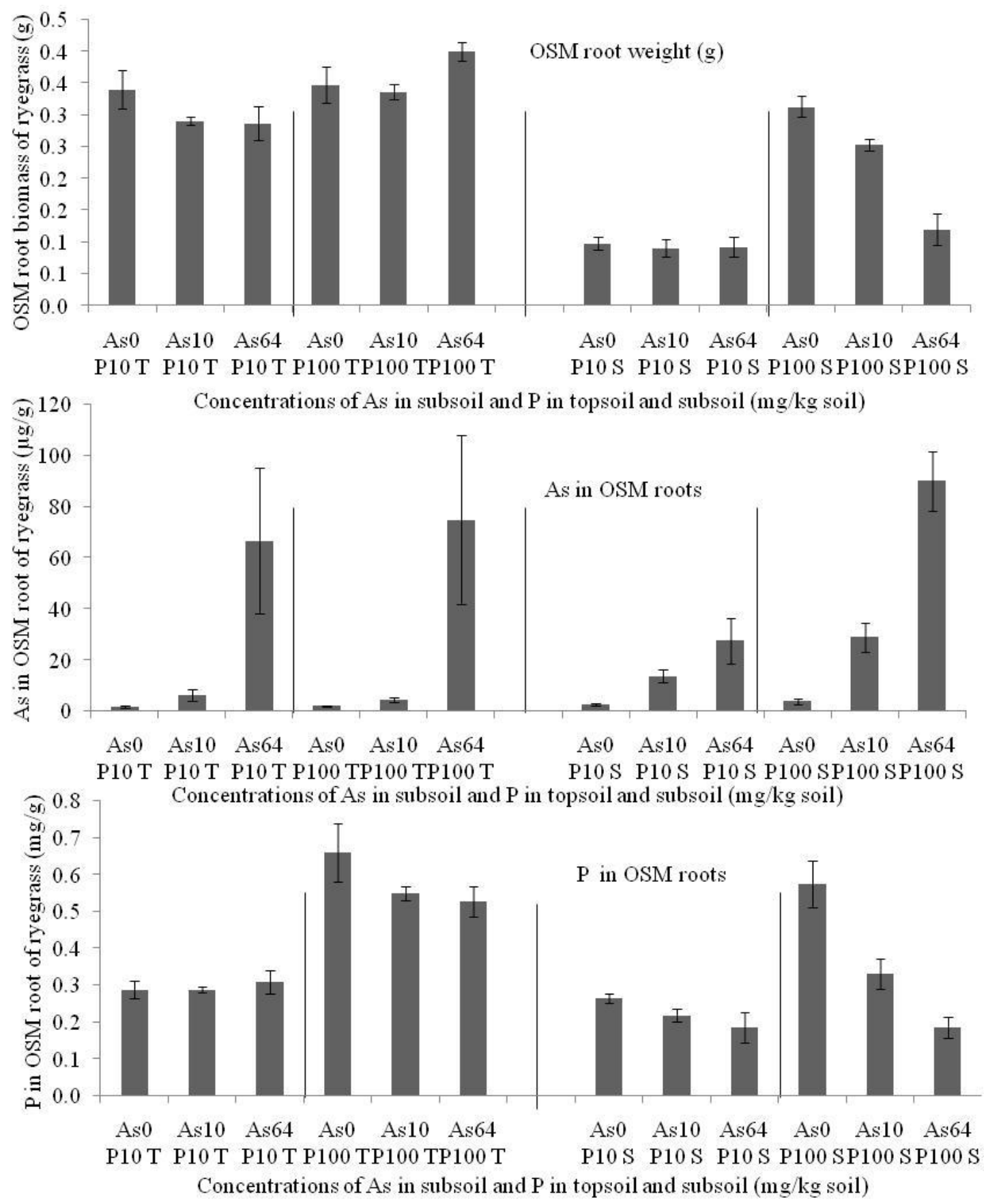

Figure 4 Mean dry OSM root weight $(\mathrm{g} \pm \mathrm{SE}, \mathrm{n}=3)$ of ryegrass plants grown in different As and $\mathrm{P}$ treatments (As in subsoil and $P$ in either topsoil or subsoil), and As and $P$ accumulation by ryegrass OSM roots 

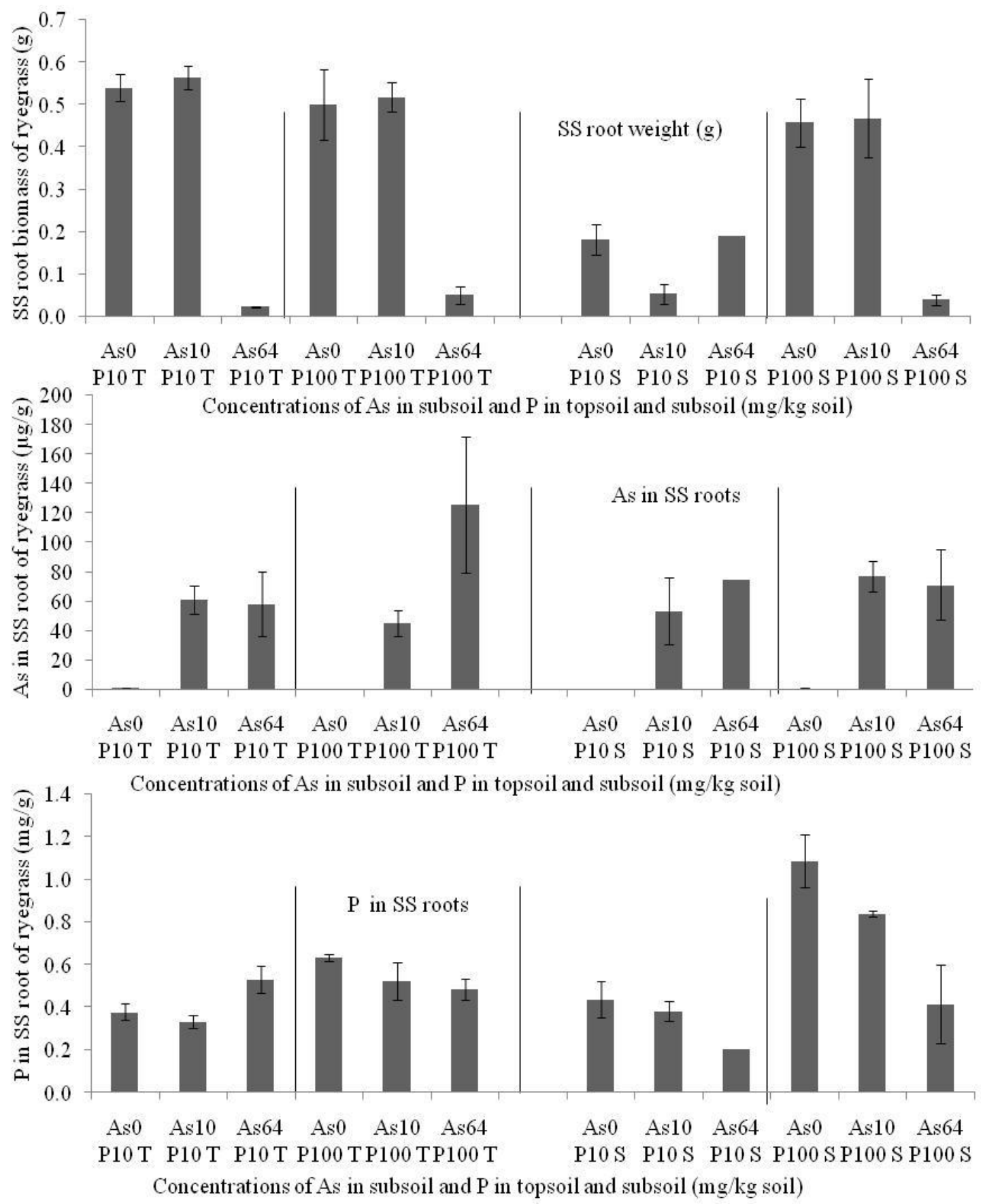

Figure 5 Mean dry subsoil (SS) root weight ( $\mathrm{g} \pm \mathrm{std}, \mathrm{n}=3$ ) of ryegrass plants grown in different As and $P$ treatments ( $A$ s in subsoil and $P$ in either topsoil or subsoil), and $A$ s and $P$ accumulation by ryegrass subsoil roots

\subsection{Treatment effects on Acacia growth and As uptake}

Where $\mathrm{P}$ was applied to topsoil, the average dry shoot weight of Acacia plants was unaffected or only slightly affected by the concentration of As in subsoil, presumably by avoiding As uptake and toxicity (Figures 6 and 7). However, where $P$ was applied to the subsoil, the shoot weight decreased with the increase of As concentrations (Figure 7). The root biomass of Acacia decreased with the increase in As concentrations, regardless of $P$ treatment. However, the root biomass was relatively less affected by As concentration with $\mathrm{P}$ applied to topsoil at either a high or low rate (Figure 8). After topsoil and subsoil P treatments at both high and low rates, the root biomass of Acacia decreased with the increase in As concentrations. But at topsoil $P$ treatment for both high and low rates, the root biomass was relatively less affected by As (Figure 8). 


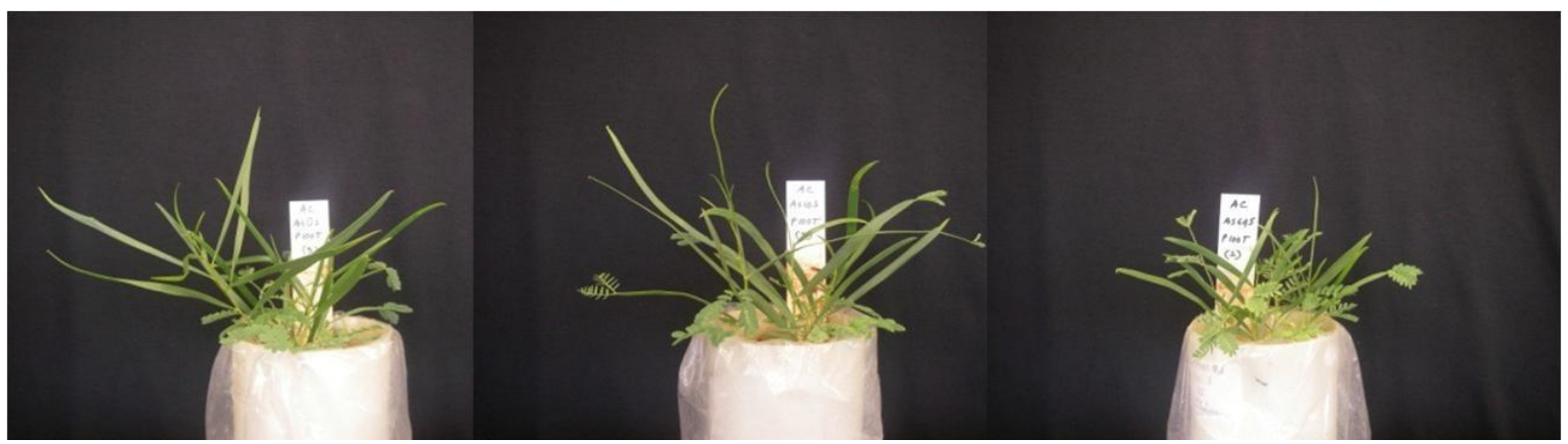

Figure 6 Acacia ancistrocarpa plants, 72 days after sowing. P applied to topsoil at $100 \mathrm{mg} / \mathrm{kg}$ (high rate). From left to right: As applied to subsoil at 0,10 or $64 \mathrm{mg} / \mathrm{kg}$
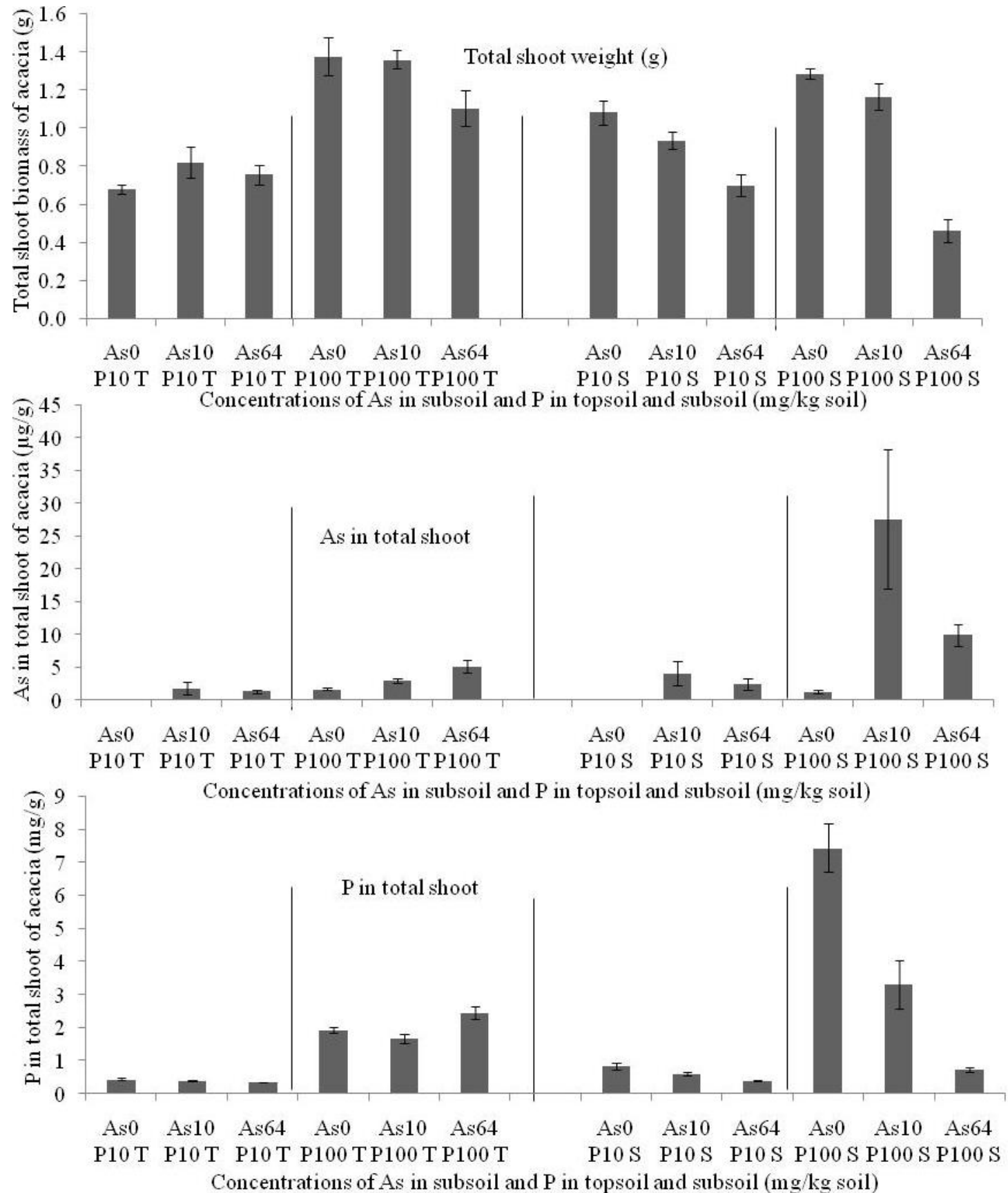

Figure 7 Mean dry shoot weight $(\mathrm{g} \pm \mathrm{SE}, \mathrm{n}=3$ ) of Acacia plants grown in different $\mathrm{As}$ and $\mathrm{P}$ treatments (As in subsoil and $P$ in either topsoil or subsoil), and As and $P$ accumulation by Acacia shoots 

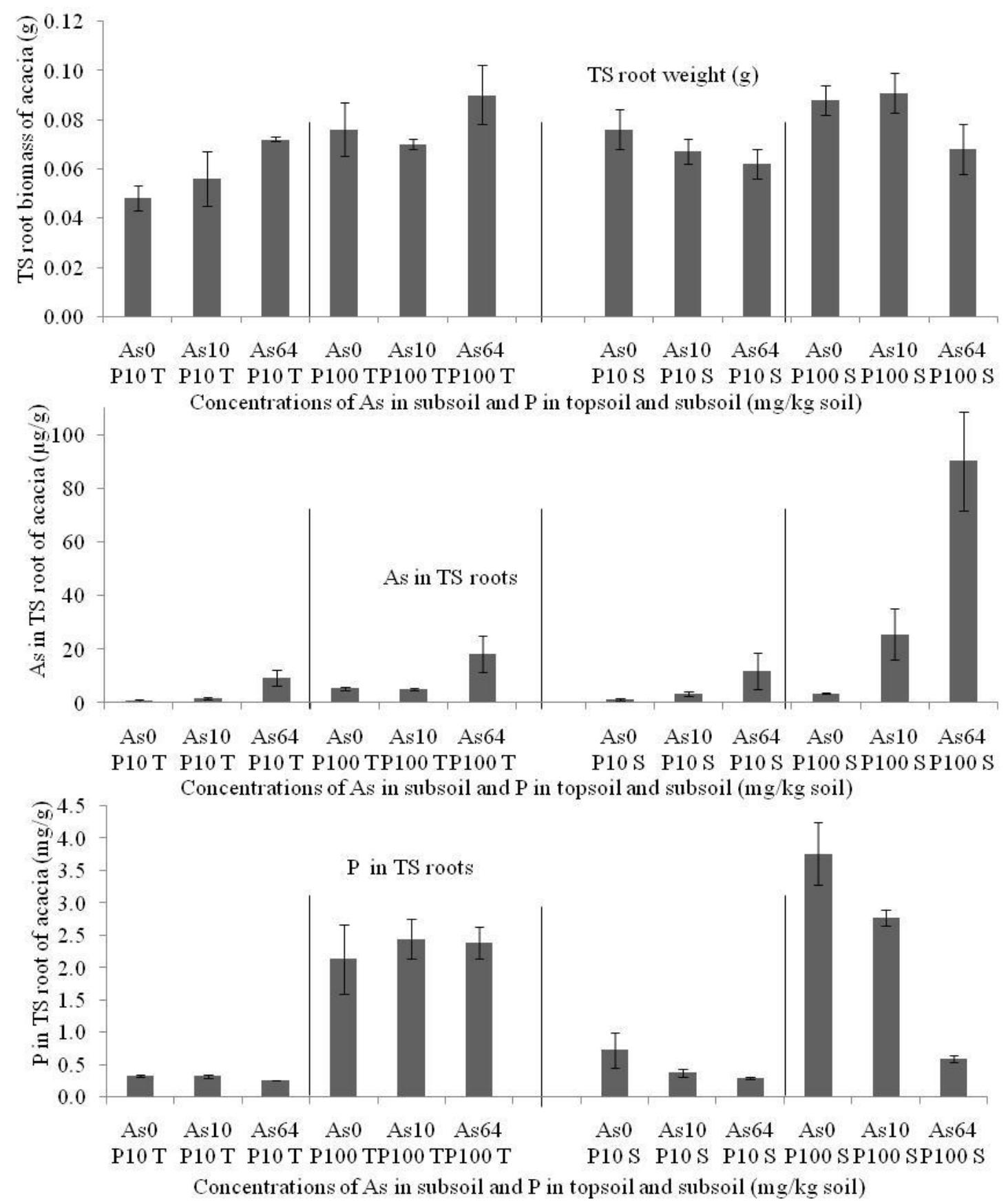

Figure 8 Average dry topsoil (TS) root weight $(g \pm S E, n=3)$ of Acacia plants grown in different As and $P$ treatments (As in subsoil and $P$ in either topsoil or subsoil), and As and $P$ accumulation by Acacia topsoil roots

\section{Discussion}

Topsoil application of $\mathrm{Pi}$ fertiliser was more effective than subsoil application for moderating As-toxicity effects for both Acacia and ryegrass, where elevated As concentrations were present in the subsoil in our simulated cover system. Application of Pi to topsoil increased $\mathrm{P}$ uptake by both ryegrass and Acacia plants, reduced the As:P ratio in shoots, and allowed plants to maintain high shoot growth where toxic concentrations of As were present in the subsoil. Ryegrass was able to achieve near-normal shoot growth even under the highest As treatments in subsoil, where a high rate of Pi was applied to topsoil (Lei et al. 2012). High P application rates nearly doubled the shoot weight of ryegrass, and also increased shoot biomass 
of Acacia, indicating that increased accumulation of $\mathrm{P}$ alleviated As toxicity and increased growth of ryegrass plants (Lei et al. 2012).

Where Pi was applied to the subsoil at a high rate, together with As, high As uptake into shoots and clear toxicity effects occurred presumably due to high availability of As after high P amendment to the subsoil (Gao \& Mucci 2001; Quaghebeur \& Rengel 2004). Plants roots exhibit rapid, localised increases in Pi uptake in response to increased Pi concentrations in the rhizosphere (Hodge 2004), and it is likely that the stimulated ion uptake from soil where high concentrations of As were present may be attributable to the observed increase in As uptake. Topsoil $P$ treatment allowed more effective $P$ acquisition that allowed the plants avoid As toxicity through competition common for carrier sites in the roots.

Arsenic uptake was consistently higher after subsoil $\mathrm{P}$ application than for topsoil $\mathrm{P}$ application, indicating that the As-P interaction in subsoil increased the As uptake by plants (Tao et al. 2006). The $P$ uptake by Acacia plants was the greatest with subsoil $P$ treatment at the high rate due to preferential growth of Acacia roots in subsoil, but not for ryegrass.

The effect of $\mathrm{P}$ amendment of root growth in the subsoil differed between the test plants. Total root biomass of Acacia was higher after subsoil amendment and opposite was found with ryegrass. Acacia produced a large proportion of the total root biomass in subsoil, while ryegrass had a large proportion of shallow roots and therefore responded well to topsoil P.

Acacia had consistently higher concentrations of As than ryegrass, and more than double the ratio of As:P in shoots more typical of As tolerant plants (Puckett et al. 2012). The As:P ratio was reduced in the shoots of both Acacia and ryegrass plants where $P$ was applied to the topsoil at the high rate, presumably due to elevated $P$ acquisition. In contrast, the As:P ratio was generally increased by application of $P$ to subsoil due to lower $\mathrm{P}$ uptake by plants irrespective of rate.

Our results show clear differences in As toxicity alleviation when applied to either topsoil or subsoil and there was variation between the two test species.

\section{Conclusion}

The growth of both Acacia ancistrocarpa and Lolium multiflorum decreased in line with increased As concentrations in subsoil irrespective of high or low $\mathrm{P}$ treatments to either topsoil or subsoil. Overall we found that $P$ application in topsoil, with As in the subsoil, was more effective than subsoil $P$ application for sustaining improved growth of plants by alleviating As toxicity.

\section{Acknowledgement}

This research was supported by the ARC Linkage project LP LP110200961.

\section{References}

Adriano, DC 1986, Trace elements in terrestrial environments, Springer-Verlag, New York, pp. 47-72.

Alvarenga, P, Gonçalves, AP, Fernandes, RM, de Varennes, A, Vallini, G, Duarte E \& Cunha-Queda, AC 2008, 'Evaluation of composts and liming materials in the phytostabilization of a mine soil using perennial ryegrass', Science of The Total Environment, vol. 406, pp. 43-56.

Alvarenga, P, Palma, P, Gonçalves, AP, Fernandes, RM, de Varennes, A, Vallini, G, Duarte, E \& Cunha-Queda, AC 2009, 'Organic residues as immobilizing agents in aided phytostabilization: (II) Effects on soil biochemical and ecotoxicological characteristics', Chemosphere, vol. 74, pp. 1301-1308.

Datta, R \& Sarkar, D 2004, 'Arsenic geochemistry in three soils contaminated with sodium arsenite pesticide: An incubation study', Environmental Geosciences, vol. 11, pp. 53-63.

Fayiga, AO \& Ma, LQ 2006, 'Using phosphate rock to immobilize metals in soil and increase arsenic uptake by hyperaccumulator Pteris vittata', Science of The Total Environment, vol. 359, pp. 17-25.

Gao, Y \& Mucci, A 2001, 'Acid base reactions, phosphate and arsenate complexation, and their competitive adsorption at the surface of goethite in $0.7 \mathrm{M} \mathrm{NaCl}$ solution', Geochimica et Cosmochimica Acta, vol. 65, pp. 2361-2378.

Gwenzi, W, Veneklaas, EJ, Holmes, KW, Bleby, TM, Phillips, IR \& Hinz, C 2011, 'Spatial analysis of fine root distribution on a recently constructed ecosystem in a water-limited environment', Plant and Soil, vol. 344, 255-272. 
Hanada, S, Nakano, M, Saitoh, H \& Mochizuki, T 1975, 'Studies on the pollution of apple orchard surface soils and its improvement in relation to inorganic spray residues', Bulletin of the Faculty of Agriculture, Hirosaki University, vol. 25, pp. 13-17.

Hodge, A, 2004 'The plastic plant: root responses to heterogeneous supplies of nutrients', New Phytologist, vol. 162.1, pp. 9-24.

Karami, N, Clemente, R, Moreno-Jiménez, E, Lepp, NW \& Beesley, L 2011, 'Efficiency of green waste compost and biochar soil amendments for reducing lead and copper mobility and uptake to ryegrass', Journal of Hazardous Materials, vol. 191, pp. 41-48.

Lambkin, DC \& Alloway, BJ 2003 'Arsenate-induced phosphate release from soils and its effect on plant phosphorus', Water, Air, and Soil Pollution, vol. 144, pp. 41-56.

Lei, M, Wan, X-M, Huang, Z-C, Chen, T-B, Li, X-W \& Liu, Y-R 2012, 'First evidence on different transportation modes of arsenic and phosphorus in arsenic hyperaccumulator Pteris vittata', Environmental Pollution, vol. 161, pp. 1-7.

Manning, BA \& Goldberg, S 1996, 'Modeling competitive adsorption of As(V) with phosphate and molybdate on oxide minerals', Soil Science Society of America Journal, vol. 60, pp. 121-131.

Marin, AR, Masscheleyn, PH \& Patrick Jr, WH 1992, 'The influence of chemical form and concentration of arsenic on rice growth and tissue arsenic concentration', Plant Soil, vol. 139, pp. 175-183.

Meharg, AA \& MacNair, MR 1992, 'Suppression of the high affinity phosphate uptake system: A mechanism of As(V) tolerance in Holcus lanatus L', Journal of Experimental Botany, vol. 43, pp. 519-524.

Puckett, EE, Serapiglia, MJ, DeLeon, AM, Long, S, Minocha, R \& Smart, LB 2012 'Differential expression of genes encoding phosphate transporters contributes to arsenic tolerance and accumulation in shrub willow (Salix spp.)', Environmental and Experimental Botany, vol. 75, pp. 248-257.

Quaghebeur, M \& Rengel, Z 2003, 'The distribution of As(V) and As(III) in shoots and roots of Holcus lanatus is influenced by arsenic resistance and As(V) and phosphate supply', Plant Physiology, vol. 132, pp. 1600-1609.

Quaghebeur, M \& Rengel, Z 2004 'Phosphate and As(V) interactions in the rhizosphere of canola (Brassica napus)', Functional Plant Biology, vol. 31, pp. 1085-1094.

Roy, WR, Hassett, JJ \& Griffin, RA 1986, 'Competitive interactions of phosphate and molybdate on arsenate adsorption', Soil Science, vol. 142, pp. 203-210.

Shaibur, MR, Adjadeh, TA \& Kawai, S 2013, 'Effect of phosphorus on the concentrations of arsenic, iron and some other elements in barley grown hydroponically', Journal of Soil Science and Plant Nutrition, vol. 13, pp. 87-98.

Smith, E, Naidu, R \& Alston, AM 2002, 'Chemistry of inorganic arsenic in soils. II. Effect of phosphorus, sodium, and calcium on arsenic absorption, Journal of Environmental Quality, vol. 31, pp. 557-563.

Smith, SE, Christophersen, HM, Pope, S \& Smith, FA 2010, 'Arsenic uptake and toxicity in plants: integrating mycorrhizal influences', Plant Soil, vol. 327, pp. 1-21.

Southworth, RM 1995, 'Part 503 land application pollutant limit for arsenic', U.S. Environment Protection Agency, Washington, DC.

Spain, AV \& Tibbett, M 2011, 'Substrate conditions, root and arbuscular mycorrhizal colonisation of landforms rehabilitated after coal mining, sub-tropical Queensland', in AB Fourie, M Tibbett, \& A Beersing (eds), Mine Closure 2011. Volume 1: Mine Site Reclamation, Australian Centre for Geomechanics, Perth, pp. 199-208.

Spain, AV, Tibbett, M, Hinz, DA, Ludwig, JA \& Tongway, DJ 2015, 'The mining-restoration system and ecosystem development following bauxite mining in a biodiverse environment of the seasonally dry tropics, Northern Territory, Australia', in M Tibbett (ed), Mining in Ecologically Sensitive Landscapes, CRC Press, Netherlands, pp. 159-227.

Tao, Y, Zhang, S, Jian, W, Yuan, C, Shan \& X-Q 2006, 'Effects of oxalate and phosphate on the release of arsenic from contaminated soils and arsenic accumulation in wheat', Chemosphere, vol. 65, pp. 1281-1287.

Taylor, G, Spain, A, Nefiodovas, A, Timms, G, Kuznetsov, V \& Bennett, J 2003, Determination of the reasons for deterioration of the Rum Jungle waste rock cover, Australian Centre for Mining Environmental Research, Brisbane.

Westheimer, FH 1987, 'Why nature chose phosphates', Science, vol. 235, pp. 1173-1178.

Woolson, EA 1973, 'Arsenic phytotoxicity and uptake in six vegetable crops', Weed Science, vol. 21, pp. 524-527. 
